\title{
PERAN GURU MATA PELAJARAN PKN DALAM PROSES IMPLEMENTASI PENDIDIKAN KARAKTER PADA SISWA
}

\author{
Rusmiati ${ }^{1}$, Andre Paulus Saleky ${ }^{2}$ \\ Sekolah Tinggi Keguruan dan Ilmu Pendidikan Biak ${ }^{1,2}$ \\ Email : $\underline{\text { rusmiati476@ yahoo.com }}^{1}$; andresaleky85@gmail.com $^{2}$
}

Naskah diterima: 12/03/2018 revisi: 09/09/2018 disetujui: 11/10/2018

\begin{abstract}
Abstrak
Penelitian ini bertujuan untuk mengetahui perencanaan pendidikan karakter dan mendeskripsikan peran guru mata pelajaran PKn dalam proses implementasi pendidikan karakter pada siswa Kelas XII SMK YPK 2 Kabupaten Biak Numfor. Metode penelitian yang digunakan deskriptif kualitatif dengan karakteristik menginterprestasikan data hasil obervasi proses pembelajaran dan hasil wawancara guru dan siswa. Adapun subjek penelitian berjumlah 43 orang terdiri 1 orang guru mata pelajaran PKn yang berperan sebagai informan utama dan 42 orang siswa kelas XII sebagai informan data primer. Selanjutnya dari hasil analisis data diketahui bahwa perencanaan pendidikan karakter di SMK YPK 2 Biak melibatkan siswa dalam kegiatan intra dan ekstra sekolah. Kegiatan intra meliputi pengorganisasian kelas seperti interaksi dalam proses pembelajaran di kelas, upacara bendera, apel pagi, ibadah singkat sebelum memulai dan mengakhiri pembelajaran sedangkan kegiatan ekstra sekolah meliputi kegiatan pramuka, olah raga, dan seni budaya. Adapun dua kegiatan ini sangat bermanfaat bagi siswa karena lewat perencanaan kegiatan yang baik maka guru dapat mendidik siswa untuk menjadi pribadi yang berkarakter.
\end{abstract}

Kata kunci: Peran Guru, Implementasi Pendidikan Karakter, Proses Pembelajaran.

\section{THE ROLE OF CIVIC EDUCATION TEACHER IN THE IMPLEMENTATION PROCESS OF EDUCATION CHARACTER}

\begin{abstract}
This study aimed to know the character education planning and to describe the role of teachers of Civics in the process of implementation of character education on the students of Class XII SMK YPK 2 Biak Numfor Regency. The research method used descriptive qualitative with the characteristics to interpret the data result of observation in the learning process and teacher and students interview. The subjects of the study were 43 people consisting of 1 person of Civics subject teachers who acted as the primary informant and 42 students of class XII as the primary informant data. Furthermore, from the results of the data analysis, it was found that the planning of character education in SMK YPK 2 Biak involved students in intra and extra school activities. Intra activities include class organizing such as interaction in the learning process in the classroom, flag ceremony, morning attendance, short worship before starting and ending learning while extra school activities include scouting, sports, and cultural arts. The two events are beneficial for students because through planning good activities the teacher can educate students to become character persons.
\end{abstract}

Keywords: Teacher Role, Implementation of Education Character, Learning Process. 


\section{PENDAHULUAN}

Perkembangan diri seseorang merupakan sebuah proses kehidupan yang membentuk karakter ke arah yang lebih baik. Menurut Suyitno (2012) untuk pengembangan pendidikan berbasis karakter memerlukan masukan-masukan antara lain menyangkut model-model pengmebangan karakter sebagai bagian yang tidak terpisahkan dari sistim pendidikan nasional. Hal tersebut bertujuan meningkatkan rasa keingintahuan diri dalam melakukan hal-hal yang bersifat positif dan menjaganya dalam lingkup kebiasaan yang secara terus menerus dilakukan atau dengan kata laini pendidikan karakter merupakan solusi dalam mengantisipasi rusaknya moral dan perilaku yang menyimpang. Zubaedi (2011) menjelaskan bahwa pendidikan karakter adalah pendidikan budi pekerti plus, yaitu yang melibatkan aspek pengetahuan (cognitive), perasaan (feeling), dan tindakan (action) hal serupa juga di buktikan oleh kajian lainya seperti Budionoi\&Feriandi, 2017; Feriandi, 2017; Marzuki\&Feriandi, 2016; Feriandi, 2017; . Hal ini sejalan dengan apa yang menjadi visi dan misi Sekolah SMK YPK 2 Biak yaitu membentuk siswa menjadi manusia yang bermoral dan berwawasan produktif, serta menyuplai sumber-sumber pendidikan agar terciptanya siswa terampil cerdas dan bertakwa kepada Tuhan Yang Maha Esa.

Berdasarkan hasil penelitian awal peneliti menemukan bahwa SMK YPK 2 Kabupaten Biak Numfor sedang berupaya mengembangkan pendidikan karakter melalui aktivitas pembelajaran dengan membiasakan siswa-siswinya untuk saling menghargai pendapat orang lain, dan untuk menghindari kebiasaan yang buruk seperti bullying (ejekan) ke temannya, membolos pada jam pelajaran, mencontek waktu ujian atau ulangan, terlambat ke sekolah, mencuri, berkelahi sesama teman, dan lain-lain. Sarbaini (2012) mengungkapkan bahwa pembinaan kepatuhan peserta didik kepada norma - norma di sekolah dilakukan melalui model pendidikan umum atau nilai dalam konteks pendidikan persekolahan dieksplorasi dari penataan iklim sekolah dan perlakuan guru terhadap peserta didik. Hal ini mengindikasikan bahwa guru memiliki peran yang penting untuk mencegah kebiasaan-kebiasaan buruk atau kasus-kasus yang marak terjadi pada lingkungan sekolah terkhususnya pada sekolah kejuruan sehingga perlu mendapakan perhatian khusus. Karena perspektif pembangunan pendidikan karakter siswa di sekolah dipercaya memiliki hubungan erat dengan terciptanya sumber daya manusia yang berkompeten pada dua sisi yakni intelektual dan moralnya. Keseimbangan kekayaan intelektual dan moral memerlukan dukungan yang kuat pula dari para pengajar yakni guru. Elfrianto (2015) mengungkapkan hal yang sama yakni sekolah memiliki potensi paling besar dalam rangka mendidik anakanak. Untuk mencapai hal tersebut maka, potensi atau usaha dilakukan oleh sekolah dapat berfokus atau tergantung pada konsep kebijakan publik dalam lingkup sekolah yang telah atau sedang ditentukan (perencanaan) guna membangun rasa sosial sebagai warga negara pendidikan. Hal ini sejalan dengan pendapat Tuasikal dan Saleky (2018) bahwa "The concept of citizenship education as one of the elements promoted in public policy" yang berarti konsep pendidikan kewarganegaraan dapat berperan sebagai salah satu elemen atau unsur yang dipromosikan dalam kebijakan publik.

Berdasarkan pengamatan tersebut, peneliti merasa tertarik dan berinisiatif untuk menggali lebih jauh apa saja peran guru mata pelajaran PKn dalam mengimplementasikan proses pendidikan karakter terkhususnya pada mata pelajaran PKn, siswa kelas XII SMK YPK 2 Kabupaten Biak Numfor, dan melakukan 
dalam proses penelitian lebih lanjut dengan mengangkat idea atau gagasan yang tertuang dalam sebuah penelitian.

Rumusan masalah penelitian ini adalah 1) Bagaimana perencanaan pendidikan karakter pada SMK YPK 2 Biak, Kabupaten Biak Numfor? dan Bagaimana peran mata pelajaran PKn dalam proses implementasi pendidikan karakter pada SMK YPK 2 Biak, Kabupaten Biak Numfor. Berdasarkan rumusan tersebut adapun penelitian ini memiliki tujuan untuk mengetahui perencanaan pendidikan karakter dan mendeskripsikan peran guru mata pelajaran PKn dalam proses implementasi pendidikan karakter pada kelas XII SMK YPK 2 Kabupaten Biak Numfor. Adapun manfaat dari penelitian ini ialah untuk mengembangkan Ilmu pengetahuan dan menambah wawasan dalam pelaksanaan pembelajaran pendidikan karakter di sekolah SMK YPK 2 Kabupaten Biak Numfor dan memberikan sumbangan pemikiran dan tolak ukur bagi para guru dan siswa khususnya di lingkungan sekolah SMK Biak Numfor dalam usaha peningkatan karakter siswa ke arah yang lebih baik.

\section{METODE}

\section{Jenis Penelitian}

Penelitian ini menggunakan metode pendekatan deskriptif kualitatif. Prabowo dan Heriyanto (2013) mendeskripsikan pendekatan deskriptif kualitatif sebagai suatu metode pengolahan data dengan cara menganalisa faktor - faktor yang berkaitan dengan objek penelitian dengan penyajian data secara lebih mendalam terhadap objek penelitian. Adapun penjabaran atau spesifikasi dalam penelitian deskriptif kualitatif ini mengarah pada jenis penelitian studi kasus yang ditujukan untuk menggambarkan serta menganalisa kejadian yang sedang belangsung dan tidak dimanipulasi. Winkel dan Hastuti, (2005) berpendapat bahwa studi kasus adalah suatu metode untuk mempelajari keadaan dan perkembangan seorang murid secara mendalam dengan tujuan membantu murid untuk mencapai penyesuaian yang lebih baik.

\section{Waktu dan Tempat Penelitian}

Lokasi penelitian ini dilaksanakan pada Kelas XII SMK YPK 2, Kabupaten Biak Numfor Provinsi Papua. Sedangkan waktu penelitian dilaksanakan pada Semester Ganjil Tahun Pelajaran 2017/2018. Adapun penelitian ini berlangsung antara bulan Agustus September, 2017.

\section{Target/Subjek Penelitian}

Nazir (2005) mengungkapkan bahwa populasi adalah kumpulan dari individu dengan kualitas serta ciri - ciri yang telah ditetapkan. Populasi dalam penelitian ini adalah seluruh siswa kelas XII SMK YPK 2 Biak yang berjumlah 42 orang dan 1 orang guru mata pelajaran PKn. Sedangkan sample penelitian menurut Sugiyono (2001) diartikan sebagai sebagian dari jumlah dan karakteristik yang dimiliki oleh populasi. Adapun sampel yang merupakan subjek dari penelitian ini adalah jumlah keseluruhan populasi penelitian yakni 43 orang yang terdiri dari 1 orang guru mata pelajaran PKn yang berperan sebagai informan data utama dan 42 orang siswa kelas XII sebagai informan data primer. Adapun sample tersebut ditentukan oleh peneliti dengan menggunakan teknik purposive sampling. Penentuan sample yakni purposive sampling seperti diungkapkan oleh Palys (2008) didasarkan pada karakteristik dan ciri yang sesuai dengan tujuan penelitian.

\section{Prosedur}

Menurut Ibnu (2003) dalam Winarno (2018) mengungkapkan bahwa prosedur yang ditempuh dalam proses pengumpulan data dapat dibedakan menjadi dua tahap, yaitu tahap persiapan dan tahap pelaksanaan. Secara umum prosedur dalam penelitian ini mengacu kepada tahapan - 
tahapan penelitian tersebut. Pada penelitian ini peneliti melakukan kegiatan observasi selama proses pembelajaran PKn di kelas dengan tujuan untuk mengetahui output pengembangan karakter siswa dan kemudian melakukan kegiatan wawancara yang datanya diperoleh atau dikumpulkan dari hasil wawancara guru mata pelajaran PKn dan para siswa Kelas XII SMK YPK 2, Kabupaten Biak Numfor.

\section{Data, Intrumen, dan Teknik Pengumpulan Data}

Instrumen dalam penelitian ini yakni lembar observasi atau pengamatan selama proses pembelajaran PKn, wawancara dan dokumentasi. Observasi dilakukan pada saat pembelajaran PKn dengan memakai tipe observasi non partisipan artinya tugas yang dilakukan oleh peneliti saat obervasi berlangsung ialah mencatat, menganalisis, dan membuat kesimpulan tentang peran guru dalam penerapan pendidikan karakter dalam mata pelajaran PKn di kelas XII SMK YPK 2 Kabupaten Biak Numfor. Atau peneliti tidak terlibat secara langsung pada saat mengobservasi. Wawancara dilakukan dengan menggunakan tipe wawancara terstruktur dibantu dengan pedoman wawancara. Responden yang diwawancarai adalah 1 orang guru mata pelajaran PKn dan 42 orang siswa kelas XII SMK YPK Biak. Sedangkan untuk instrumen tambahan seperti dokumentasi berupa dokumen profile sekolah dan foto-foto yang berkaitan dengan penerapan pendidikan karakter dalam pembelajaran PKn di kelas XII SMK YPK Biak, Kabupaten Biak Numfor.

Sedangkan pengambilan data dari dokumentasi dapat di ketahui bahwa SMK YPK 2 adalah bekas atau gedung peninggalan belanda yang dibangun sekitar Tahun 157 sebagai gedung LTS (Lagree Techniche School) yang didirikan oleh SCO (Sticting Christelyke Opleding) yang menampung lulusan ELS (Europese Large School) yang merupakan Sekolah Dasar (SD) jaman Belanda. Pada saat didirikanya telah dibuka dua jurusan Metal Bewerking (Jurusan Mesin) dengan ketua jurusan Mr. C.J Baker dan Hout Bewerking (Jurusan Bangunan) dengan Ketua Jurusan $\mathrm{Mr}$. Hendrik Maat yang sekaligus menjadi direktur LTS. LTS dalam operasinya menggunakan pola asrama (Internaat) dengan jumlah siswa sebanyak 80 orang. Pada bulan Agustus - Oktober 1962 terjadi masa transisi dari pemerintah Kolonial Belanda ke pemerintahan Indonesia. Pejabat yang ditunjuk pada masa transisi pada saat itu adalah Bapak Guru Y. M. Aibekob, yang dibantu oleh tiga orang bguru lainnya yaitu Bapak Guru A Sroyer, Bapak Guru Y Mayor, dan Bapak Guru S. Bonsapia. Pada bulan Desember, Tahun 1962 didirikan Guru Trikora dari Jakarta yaitu Bapak CH. Marten sekaligus sebagai Direktur LTS. Pada tanggal 8 Maret 1963, Stchting Christelyke Opleding (SCO) dirubah menjadi Yayasan Pengajaran Kristen (YPK).

Pada Bulan Oktober 1963, terjadi serah terima dari pemerintah Hindia Belanda ke Pemerintah Indonesia, sehingga LTS diganti nama menjadi Sekolah Teknik Setingkat (SLTP) yang berpola asrama dengan dua rombongan belajar, hingga sekolah ini pada akhirny tutup pada tahun 1987. Pada tahun 1985 Sekolah teknik Menengah dibuka di Biak dengan Kepala Sekolah Bapak Guru A. Sroyer dan operasionalnya atau proses pembelajarannya dilakukan pada sore hari di gedung Sekolah Teknik. Sejak dibukanya Sekolah Teknik Biak, sejak tahun 1985 memiliki tiga jurusan yaitu: Teknik Bangunan, Teknik Mesin, dan Teknik Mekanik Otomotif dengan 10 kelas dan jumlah murid sebanyak 417 orang. Sejak berdirinya SMK YPK 2 Biak telah menghasilkan banyak lulusan. Adapun alumni SMK YPK 2 Biak telah banyak bekerja di berbagai instansi Pemerintah, Perusahan Swasta, dan banyak pula yang bekerja sebagai pekerja mandiri.

Visi SMK YPK 2 Biak Kabupaten Biak Numfor adalah terwujudnya suatu 
lembaga diklat yang profesional pada bidang teknologi dan rekayasa. Sedangkan misi yakni a) Memenuhi tuntutan antara dunia kerja dan dunia pendidikan, b) Meningkatkan profesionalisme guru dalam melakukan kegiatan diklat siswa, c) Mendidik dan melatih tenaga kerja yang ahli di bidang Teknologi dan Rekayasa, d) Membentuk siswa yang menjadi manusia yang berwawasan produktif dan e) Menyuplai sumber - sumber pendidikan agar terciptanya siswa terampil cerdas dan bertaqwa kepada Tuhan Yang Maha Esa.

Tujuan SMK YPK 2 Biak Kabupaten Biak Numfor adalah untuk a) Menyiapkan peserta didik agar menjadi manusia produktif, mampu bekerja mandiri, mengisi lowongan pekerjaan yang ada di DU/DI sebgai tenaga kerja tingkat menengah sesuai dengan kompetensi pada program keahlian yang dipilihnya, b) Menyiapkan peserta didik agar mampu memilih karier, ulet, dan gigih dalam berkompetisi, c) Menyiapkan peserta didik dengan ilmu pengetahuan, teknologi, dan seni agar mampu agar mampu mengembangkan diri dikemudian hari baik secara mandiri maupun melalui jenjang pendidikan yang lebih tinggi dan d) Membekali peserta didik dengan kompetensi-kompetensi yang sesuai dengan program keahlian yang dipilih.

\section{Teknik Analisis Data}

Data yang diperoleh dari hasi penelitian kemudian dianalisa menggunakan teknik analisis data deskriptif kualitatif dengan cara menginterprestasikan hasil data lapangan (observasi dan wawancara) serta dokumentasi dalam kata - kata atau kalimat secara deskriptif. Hal ini sejalan dengan apa yang dikemukakan oleh Sugiyono (2013) bahwa data kualitatif merupakan data yang berbentuk kata dan kalimat, serta dokumen lainnya

\section{HASIL DAN PEMBAHASAN}

\section{Hasil Penelitian}

Hasil penelitian ini di bagi dalam tiga jenis yakni observasi, wawancara dan dokumentasi. Berikut penjelasan lebih rinci mengenai hasil penelitianya

Melalui observasi atau pengamatan penelitian dilakukan 1 kali pertemuan yaitu pada hari Senin, 23 Agustus 2017 berupa pengamatan kegiatan pembelajaran di Kelas XII SMK YPK 2 Kabupaten Biak Numfor tekhususnya pada mata pelajaran $\mathrm{PKn}$, adapun aspek yang menjadi pengamatan penelitian dapat diuraikan secara deskriptif sebagai berikut;

Dari hasil observasi dilaporkan bahwa salah satu aspek yang mempengaruhi keberhasilan pembelajaran adalah kemampuan guru dalam mengelola pembelajaran sehingga menjadi suatu proses yang bermakna dan kondusif dalam pembentukan karakter siswa. Oleh karena itu, kegiatan belajar selain dikembangkan secara sistematis, efektif, dan efisien, juga perlu bervariasi. Hal ini sangat penting karena suasana pembelajaran yang menyenangkan dapat menarik perhatian siswa agar tetap fokus pada materi yang disampaikan. Selama proses belajar, guru juga mampu mengarahkan siswa untuk dapat mengambil pesan moral dari apa yang diajarkan.

Sebagai contoh pendidikan karakter yang ditanamkan pada siswa - siswi SMK YPK 2 Kabupaen Biak Numfor khususnya bagi siswa kelas XII, yaitu (Siswa dilatih agar tetap disiplin, masuk tepat waktu sesuai waktu yang telah ditentukan (tidak terlambat sekolah); Siswa dilatih untuk menjaga kebersihan dan kerapihan diri; Siswa dilatih menjaga kebersihan kelas dan lingkungan sekolah; Siswa dilatih untuk memiliki karakter yang religius seperti berdoa sebelum melaksanakan proses kegiatan belajar mengajar; Toleransi saat dikelas seperti menghormati sesama siswa; Menanamkan pada diri siswa untuk saling tolong menolong antar sesama siswa dan orang lain; Menanamkan diri siswa tentang bagaimana bersifat sifat jujur yaitu tidak 
boleh mencontek saat ulangan maupun ujian di sekolah, dan masih banyak lagi hal yang menyangkut pendidikan karakter yang ditanamkan pada siswa.

Melalui Wawancara guru yang dilaksanakan pada hari Rabu, 30 Agustus 2017, dan yang menjadi responden adalah guru mata pelajaran PKn Kelas XII yakni Ibu. Drs. Maria Korwa, S.Pd., MM yang juga menjabat sebagai Kepala SMK YPK 2 Kabupaten Biak Numfor. Dari data hasil wawancara dapat dijelaskan secara deskriptif sebagai berikut:

Dalam pembelajaran Pendidikan Kewarganegaraan merupakan mata pelajaran untuk membentuk watak atau moral anak (siswa) menjadi lebih baik dalam perilaku sehari-hari.

Peran guru dari mata pelajaran PKn untuk mengembangkan nilai-nilai karakter yang baik pada siswa di Kelas XII SMK YPK 2 Biak yaitu mengintegrasikan yang baik itu dalam setiap pengajaran sesuai dengan kompetensi dasar atau materi yang diberikan setiap mata pelajaran berlangsung.

Rencana program pengembangan karakter untuk memotivasi siswa yaitu dengan melibatkan siswa dalam kegiatankegiatan baik baik kegiatan intra sekolah maupun ekstra sekolah, seperti organisasi kelas, yaitu bekerja sama tentang tentang kegiatan kelas, upacara bendera, apel pagi, ibadah singkat sebelum belajar dan berakhir, dan lain-lain (intra sekolah), sedangkan kegiatan ekstra sekolah yaitu: pramuka,olah raga, seni budaya.

Dalam hal pengembangan implementasi pembelajaran PKn yang dilakukan guru guna mewujudkan pembentukan karakter siswa melalui pemberian pelatihan kelas dalam tugas-tugas organisasi kelas untuk dikembangkan sebelum pembelajaran seperti: masuk tepat waktu, berdoa, melaksanakan tugas dari guru PKn, mengumpulkan tugas pekerjaan rumah tepat waktunya, kebersihan kelas, adil dalam pembagian tugas
Nilai-nilai yang diintegrasikan dalam pendidikan kewarganegaraan yaitu seperti disiplin, jujur, bertanggung jawab, cinta damai, rasa ingin tahu, senang membaca, tegasn menegakkan kebenaran, adil, kreaktif, komitmen, berani menanggung resiko, semangat kebangsaan, peduli sosial, peduli lingkungan, toleran, saling berbagi, respek (selain karakter bangsa dimasukkan juga nilai ekonomi, kreaktif, dan kewirausahaan).

Bentuk nyata pengembangan nilainilai karakter yang diajarkan dapat diimplementasikan oleh siswa yakni nilai intra sekolah seperti upacara bendera, apel pagi, ibadah singkat sebelum belajar dan berakhir, UKS, cerdas cermat, diskusi kelompok, seminar kecil dalam kelas, pendidikan sistem ganda selama tiga bulan didunia usaha dan industri. sedangkan nilai ekstra sekolah yaitu seperti: pramuka, olah raga, seni budaya (seni lukis, seni tari, seni drama, seni suara).

Beberapa hal yang menjadi hambatanhambatan dalam proses pengembangan nilai-nilai karakter siswa yaitu misalnya: jarak antara sekolah dengan tempat tinggal jauh yang dapat menyebabkan siswa terlambat, kadang sering bolos sekolah, kurangnya perhatian dari orang tua terhadap anaknya, pengaruh lingkungan yang kurang sehat, ada juga pengaruh dari permasalahan orang tuanya sehingga mempengaruhi karakter anak, contohnya:seperti kekerasan dalam keluarga, orang tua pisah (cerai), dan masalah perekonomian dalam keluaraga sehingga dapat menyebabkan anak nekat untuk mencuri, mabuk, bahkan terjerumus dalam pemakaian obat-obat terlarang. Dalam mengatasi hambatan-hambatan tersebutguru PKn harus konselingkan kepada guru BP, guru kelas, bahkan agama untuk mencari permasalahannya atau jalan kelur dari masalah dan menyelesaikannya.

Program ekstrakulikuler yang berhubungan dengan pengembangan 
pendidikan karakter yang diberikan kepada siswa yaitu seperti kegiatan pramuka, olah raga, seni budaya, pelajaran agama, dan paduan suara kegereja-gereja. Sedangkan untuk menilai tolak ukur dalam perkembangan karakter dapat dilihat dari hasil kelulusan siswa yaitu mencapai $100 \%$ setiap tahunnya sebab sudah disaring dari kelas satu hingga kelas dua, hal ini dilihat dari sistem kuanitatif. Dan kualikatifnya belum tentu mencapai $100 \%$ karena berbeda karakter".

Dalam penelitian ini wawancara siswa dilakukan untuk memperoleh informasi timbal balik atau hubungan antara kegiatan siswa dalam meningkatkan prestasi dan untuk dapat mengetahui sejauh mana siswa dapat memahami nilai-nilai moral pendidikan karakter yang diajarkan oleh guru mata pelajaran PKn dalam proses kegiatan belajar mengajar.

Adapun wawancara dilaksanakan pada hari Senin 13 September 2017 dan yang menjadi responden adalah Siswa Kelas XII SMK YPK 2 Kabupaten Biak Numfor sebanyak 42 orang siswa. Pertanyaan wawancara terdiri dari 5 pertanyaan yang wajib dijawab oleh siswa. Data hasil wawancara yang telah diperoleh selanjutnya dapat dideskripsikan sebagai berikut:

Mengenai pendidikan karakter 32 orang siswa berpendapat bahwa "Karakter adalah watak, sifat, atau perilaku, akhlak ataupun kepribadian yang membedakan seseorang individu dengan individu yang lain. Dan pendidikan karakter yaitu suatu sistem yang menanamkan nilai-nilai karakter kepada seseorang untuk menjadi lebih baik,yang meliputi ilmu pengetahuan, kesadaran, kemauan, dan tindakan untuk dapat melaksanakan nilai-nilai tersebut terhadap Tuhan Yang Maha Esa, diri sendiri, orang lain, lingkungannya maupun bangsa dan negaranya."

Mengenai peran guru PKn dalam mendorong anda (siswa) menjadi pribadi yang berkarakter 26 orang siswa menjawab pertanyaan soal kedua yaitu "Ya, guru mempunyai peranan, mendorong, dan mengajar siswa agar menjadi siswa yang berkarakter dan mempunyai pribadi yang baik di sekolah maupun di luar lingkungan sekolah"

Peran guru PKn mengajarkan nilai nilai moral terhadap anda (siswa) selaku peserta didik dalam kegiatan pembelajaran di kelas yaitu memberikan pengajaran dan keteladanan tentang nilai-nilai moral seperti: menghargai dan menghormati guru dan orang lain, sopan santun, tolong menolong, kejujuran, kedisiplinan, ketakwaan, dan lain-lain, untuk mendorong siswa menjadi pribadi yang baik

Nilai - nilai apa saja yang dikembangkan melalui proses pembelajaran PKn di kelas dan berpengaruh bagi perkembangan karakter siswa yakni Nilai hubungan dengan Tuhan seperti nilai religius atau nilai keagamaan. Nilai hubungan dengan sesama, seperti: menghargai hak dan kewajiban orang lain, selalu patuh terhadap peraturan sosial (berhubungan dengan kepentingan umum atau masyarakat), sopan santun menghormati, ramah dan perilaku baik terhadap orang lain, menghargai karya dan prestasi oranjg lain, mengakui dan menghormati apa yang sudah dicapai oleh orang lain, demokratis. Nilai hubungan dengan diri sendiri yaitu: bersikap jujur, selalu bertanggung jawab, selalu disiplin, selalu bekerja keras, berpola hidup sehat, percaya diri, mandiri, rasa ingin tahu yang tinggi, cinta terhadap ilmu pengetahuan, selalu berpikir logis, kritis, dan inovatif. Nilai hubungan dengan lingkungan, seperti: rasa perduli terhadap lingkungan, peduli sosial, menghargai keberagaman atau perbedaan dan nilai kebangsaan"

Sedangkan nilai-nilai karakter yang dapat diwujudkan bukan hanya di lingkungan sekolah tetapi juga di luar lingkungan sekolah nilai - nilai moral 
seperti: sopan santun, saling tolong menolong bagi yang membutuhkan bantuan, menghormati orang tua dan orang lain, mengikuti kegiatan keagamaan, organisasi masyarakat dan mentaati aturan yang ada di masyarakat."

\section{Pembahasan}

Perencanaan Pendidikan Karakter di SMK YPK 2 Kabupaten Biak Numfor

Berdasarkan hasil wawancara guru mata pelajaran PKn sebagai informan utama dapat dijelaskan bahwa rencana program pengembangan karakter untuk memotivasi siswa Kelas XII SMK YPK 2 Biak yaitu dengan melibatkan siswa dalam kegiatankegiatan, baik kegiatan intra sekolah seperti: organisasi kelas, upacara bendera, apel pagi, ibadah singkat sebelum belajar dan berakhir, dan lain-lain. Sedangkan kegiatan ekstra sekolah meliputi: kepramukaan, olah raga, dan seni budaya (seni tari, seni lukis, seni suara: seperti kegiatan koor remaja gereja). Perencanaan pendidikan karakter harus berdasarkan pada visi pendidikan yang ditetapkan oleh sekolah yaitu terwujudnya suatu lembaga diklat yang profisional di bidang teknologi dan rekayasa serta menjadi siswa yang bertakwa kepada Tuhan Yang Maha Esa, dan merupakan cita-cita yang akan diarahkan melalui kinerja lembaga pendidikan. Tanpa visi yang diungkapkan melalui pernyataan yang jelas dan dapat dipahami oleh semua pihak yang terlibat di dalam lembaga pendidikan tersebut, setiap usaha pengembangan pendidikan karakter akan menjadi sia-sia. Sedangkan misi adalah sebuah usaha menjembatani praktis harian di lapangan dengan cita-cita ideal yang menjiwai seluruh gerak lembaga pendidikan.

Tercapainya misi merupakan tanda keberhasilan melaksanakan visi secara konsisten. Jadi perencanaan pendidikan karakter adalah proses menentukan nilainilai. Hal yang sangat mendasar ketika memulai pendidikan karakter adalah menentukan nilai-nilai yang akan ditanamkan atau dibelajarkan pada peserta didik. Menurut Hayes (2003), proses penentuan nilai ini harus melibatkan komunitas sekolah yakni guru, orang tua, dan masyarakat sekitar, sehingga sekolah akan mencerminkan keseluruhan komunitas yang mereka layani, mampu melahirkan peserta didik dengan karakter sesuai harapan komunitas. Selain itu, Budiningsih (2004) menegaskan bahwa terdapat beberapa unsur yang turut berpengaruh dalam penentuan muatan pendidikan moral yakni 1) Karakteristik anak didik yang meliputi latar ekonomi, agama, budaya serta tahap perkembangan kognitif dan moral. 2) Konteks sekolah berada meliputi budaya masyarakat dan falsafah negara.

Dalam hal perwujudan pendidikan moral maka perlu diterapkannya proses integrasi pendidikan karakter yang baik dalam sebuah pembelajaran di lingkungan sekolah sehingga memiliki manfaat bagi lingkungan masyarakat. Hal ini sejalan dengan pendapat Haryati (2017) bahwa materi pembelajaran yang berkaitan dengan norma atau nilai - nilai pada setiap mata pelajaran perlu dikembangkan, dieksplisitkan, dikaitkan dengan konteks kehidupan sehari-hari. Ada beberapa kriteria nilai yang bisa menjadi bagian dalam kerangka pendidikan karakter yang dilaksanakan di sekolah SMK YPK 2 Kabupaten Biak Numfor antara lain: a) Nilai keutamaan, Nilai keindahaan, b) Nilai kerja, c) Nilai cinta tanah air, d) Nilai demokrasi, e) Nilai kesatuan, Nilai moral, f) dan g) Nilai kemanusiaan.

\section{Peran Guru Mata Pelajaran PKn dalam Proses Implementasi Pendidikan Karakter pada Kelas XII SMK YPK 2 Kabupaten Biak Numfor. \\ Dari hasil observasi dijelaskan} bahwa proses implementasi pendidikan karakteri pada proses pembelajaran PKn, guru juga menanamkan dan mengembangkan nilai-nilai berbudi pekerti yang bermanfaat bagi kehidupan siswa dalam hal menghargai orang lain dan 
bertindak sopan, jujur, adil, saling menghormati, disiplin dan berkarakter baik sesuai dengan norma atau aturan agama. Hal ini juga diperkuat oleh hasil wawancara dengan guru mata pelajaran PKn selaku objek wawancara bahwa SMK YPK 2 Biak memiliki program pengembangan karakter yang bertujuan memotivasi atau mendorong terbentuknya karakter siswa dengan melibatkan siswa dalam kegiatan-kegiatan baik baik kegiatan intra sekolah maupun ekstra sekolah, seperti organisasi kelas, yaitu bekerja sama tentang tentang kegiatan kelas, upacara bendera, apel pagi, ibadah singkat sebelum belajar dan berakhir, dan lain - lain (intra sekolah), sedangkan kegiatan ekstra sekolah yaitu: pramuka, olahraga, seni budaya.

Dari hasil wawancara dengan siswa juga diketahui bahwa untuk upaya pembentukan nilai karakter siswa guru mempunyai peranan yang paling krusial yakni menyemangati dan mengajar siswa agar menjadi siswa yang berkarakter dan mempunyai pribadi yang baik di sekolah maupun di luar lingkungan sekolah. Pendidikan karakter menurut Lickona (2004) mengandung tiga unsur pokok, yaitu mengetahui kebaikan (knowing the good), mencintai kebaikan (desiring the good), dan melakukan kebaikan (doing the good). Siswa juga menambahkan bahwa nilai-nilai karakter dapat diwujudkan dengan cara menanamkan nilai - nilai moral seperti: sopan santun, saling tolong menolong bagi yang membutuhkan bantuan, menghormati orang tua dan orang lain, mengikuti kegiatan keagamaan, organisasi masyarakat dan menaati peraturan yang ada di masyarakat.

Selanjutnya untuk menilai apakah siswa telah benar-benar berkembang karakternya, dari hasil wawancara guru mengungkapkan bahwa perkembangan karakter dapat dilihat dari hasil kelulusan siswa yaitu mencapai $100 \%$ setiap tahunnya sebab sudah disaring dari kelas satu hingga kelas dua dan kualifikasinya belum tentu mencapai $100 \%$ karena berbeda karakter.
Berdasarkan hasil wawancara dari guru mata pelajaran PKn maupun siswa dapat disimpulkan bahwa pengertian karakter adalah nilai-nilai yang berkaitan dengan kesosialan, dengan tujuan membentuk pribadi anak supaya menjadi manusia yang baik, warga masyarakat, dan warga negara yang baik, serta dapat mempengaruhi diri sendiri dan orang lain apabila diimplementasikan dalam kehidupan sehari-hari.

\section{SIMPULAN DAN SARAN Simpulan}

Berdasarkan data hasil penelitian dan pembahasan dapat disimpulkan bahwa perencanaan pendidikan karakter pada SMK YPK 2 Kabupaten Biak Numfor adalah usaha atau kegiatan yang bertujuan untuk memotivasi siswa dengan melibatkan mereka dalam kegiatan-kegiatan, baik kegiatan intra sekolah seperti: organisasi kelas, upacara bendera, apel pagi, ibadah singkat sebelum belajar dan berakhir, dan lain-lain. Sedangkan kegiatan ekstra sekolah meliputi: kepramukaan, olah raga, dan seni budaya (seni tari, seni lukis, seni suara: seperti kegiatan koor remaja gereja) yang didasarkan pada visi dan misi SMK YPK 2 Kabupaten Biak Numfor. Adapun dalam proses implementasinya mengacu pada kriteria nilai yang menjadi bagian dalam kerangka pendidikan karakter yang dilaksanakan di sekolah SMK YPK 2 Kabupaten Biak Numfor antara lain: a) Nilai keutamaan, Nilai keindahaan, b) Nilai kerja, c) Nilai cinta tanah air, d) Nilai demokrasi, e) Nilai kesatuan, Nilai moral, f) dan g) Nilai kemanusiaan.

Selanjutnya dari hasil deskripsi peran guru mata pelajaran PKn dalam proses implementasi pendidikan karakter pada kelas XII SMK YPK 2 Kabupaten Biak Numfor, para siswa mengungkapkan bahwa guru mata pelajaran PKn mempunyai andil yang besar dalam hal memotivasi siswa agar 
menjadi pribadi yang berkarakter yang dapat diimplementasikan serta diwujudkan melalui penanaman nilai - nilai moral seperti: sopan santun, saling tolong menolong bagi yang membutuhkan bantuan, menghormati orang tua dan orang lain, mengikuti kegiatan keagamaan, organisasi masyarakat dan menaati peraturan yang ada di masyarakat yang diajarkan oleh guru selama proses pembelajaran PKn di kelas.

Saran

Faktor terpenting untuk mewujudkan keberhasilan pendidikan karakter di sekolah memerlukan partisipasi guru yang intensif dalam proses pembelajaran sehingga dapat memberikan manfaat bagi siswa. Perencanaan program pendidikan karakter dan peran guru mata pelajaran dalam kaitannya dalam lingkungan SMK YPK 2 Kabupaten Biak Numfor sebagai lembaga pendidikan vokasi diharapkan dapat terus dipertahankan dan dikembangkan lagi sehingga dapat menjawab atau mengatasi tantangan-tantangan yang bisa saja akan terjadi secara tidak terduga di masa yang akan datang.

\section{DAFTAR PUSTAKA}

Budiyono, B., \& Feriandi, Y. A. (2017). Menggali Nilai Nilai Kearifan Lokal Budaya Jawa Sebagai Sumber Pendidikan Karakter. In Prosiding Seminar Nasional Bimbingan dan Konseling (Vol. 1, No. 1, pp. 92-103).

Elfrianto. (2015). Urgensi Keseimbangan Pendidikan Budi Pekerti di Rumah dan di Sekolah, Jurnal Edu Teach. Vol, 1 Maret 2015 ISSN: 2442.6024.

Haryati, S. (2017). Pendidikan Karakter dalam Kurikulum 2013. Tersedia secara online di:http://lib.untidar.ac.id/wpcontent/uploads.

Hayes, G.K. (2003). Whoes Volues Do We Teach ? Delta Kappa Gamma Bull. Vol 69, No. 3, pp.55.57.
Ibnu S., Mukhadis A., dan Dasna, I.W. (2003). Dasar-Dasar Metodologi Penelitian. Malang: Penerbit Universitas Negeri Malang.

Lickona. (2004) charact Hatter: How to Help Our Children Develop Good Judgment, Integrity, and Other Esential Virtnes. Newyork:

Simon\&Schuters, Inc.

Marzuki, M., \& Feriandi, Y. A. (2016). Pengaruh Peran Guru Ppkn dan Pola Asuh Orang Tua terhadap Tindakan Moral Siswa. Jurnal Kependidikan: Penelitian Inovasi Pembelajaran, 46(2), 193-206.

Nazir. (2005). Metode Penelitian, Jakarta: Ghalia Indonesia.

Palys, T. (2008) Purposive Sampling. In L M. Given (Ed.). The Sage Encyclopedia of Qualitative Research Methods. (Vol 2). Sage: Los Angeles, pp. 697-8.

Prabowo, A. dan Heriyanto. (2013). Analisis Pemanfaatan Buku Elektronik ( EBook ) Oleh Pemustaka Di Perpustakaan Sma Negeri 1 Semarang. Jurnal Ilmu Perpustakaan. Volume 2, Nomor 2, Tahun 2013 Hal 1-9.

Sarbaini (2012). Pembinaan Kepatuhan Peserta Didik Terhadap Norma Sekolah; Studi Kasus di SMA Korpri Banjarmasin. Jurnal Pendidikan Kewarganegaraan Universitas Lambung Mangkurat. Vol. 2 No. 10 Nopember 2012. ISSN: 2303-2979.

Sugiyono. (2001). Statistika untuk Penelitian, Bandung: Alfabeta.

Sugiyono. (2013). Metode Penelitian Kuantitatif, Kualitatif dan $R$ \& $D$. Bandung: Alfabeta

Suyitno, Imam. (2012). Pengembangan Pendidikan Karakter dan Budaya Bangsa Berwawasan Kerarifan Lokal. Jurnal Pendidikan Karakter, Tahun II, Nomor 1, Februari 2012.

Tuasikal, P., \& Saleky, A. P. (2018). The Theory of Citizenship as A Medium in 
Citizenship Jurnal Pancasila dan Kewarganegaraan Vol 6 No 2 Oktober 2o18, hal 79-89

Avaliable online at : http://e-journal.unipma.ac.id/index.php/Citizenship

Print ISSN: 2302-433X Online ISSN : 2579-5740

Promoting Public Policy. CivicCulture: Jurnal Ilmu Pendidikan PKN dan Sosial Budaya, 2(2), 145-152.

Winarno, M. E. (2018). Metedologi Penelitian dalam Pendidikan Jasmani.Universitas Negeri Malang (UM) Press. ISBN. 979.495.673.2
Winkel dan Hastuti. (2005). Bimbingan dan Konseling di Institusi Pendidikan. Jakarta: Gramedia

Zubaedi (2011) Desain Pendidikan Karakter. Jakarta Kencana. 